cult by the extensive work of the Darwin scholars themselves. The mass of archival material, correspondence and commentary now accumulated around the man has become so immense that it is almost impossible to condense.

Janet Browne's splendid book is the first volume of a patient analysis of Darwin's entire life in the light of all these sources. Her qualifications as a trained biologist, historian of science and skilled editor of the correspondence project put her in an ideal position to do this challenging work. To those aware of contemporary Darwin studies, the events, characters, work and basic plot of Darwin's life up to 1856 remain generally unaltered in her study. The novelty is in its emphasis on issues and individuals ignored by others and on the scientific dimensions of Darwin's life. Browne's account is strictly chronological, beginning with the young gentleman at the Mount in Shrewsbury in the world of Jane Austen. We follow him from his chemistry experiments with his elder brother Eramus to his medical (and natural history) studies at Edinburgh, Cambridge, the Beagle voyage, London and finally to Down House where the book ends with Darwin's return in May 1856 to the "species question".

Those looking for history with an agenda will be disappointed. If Browne makes Darwin into a product of his times, a man whose "theory of natural selection could only have emerged out of the competitive context of Victorian England", she does not try to reduce the content of his scientific work to the interplay of Victorian social forces and class conflicts. And she makes little effort to psychoanalyse her subject. Even Darwin's debilitating illness, which has tantalized both parasitologists and professional psychoanalysts, lurks in the background except when it interrupts his scientific work, as with his threemonth stay in 1849 at Malvern where he was initiated into the rigours of Dr James Manby Gully's famous water cure.

Browne sensitively reveals the person behind the correspondence and notebooks. She is scrupulously faithful to the texts and the documents in constructing her narrative. Where evidence is slight, such as in the case of Darwin's possible liaison with Fanny Owen of the "Housemaid and Postillon" letters, she simply admits that there is little to conclude, and on the whole allows the social proprieties of the Regency world to decide the issues. Her analyses are exact, plausible and eminently judicious.

Browne's most important 'revelation' is perhaps the important role finally given to Charles's elusive elder brother Erasmus, his first scientific mentor. Erasmus's preparation of the way for Charles's initiation into the Cambridge network has previously received little attention. Their close relationship in the years between Charles's return from the Beagle voyage and his marriage to Emma Wedgwood shines through in the correspondence, but it has needed expanding and deepening. Browne has fleshed out Erasmus's character in fine detail, portraying his circle of associates, his scientific and other intellectual interests and his curiously flaccid personality.

Browne's earlier book on the history of biogeography (The Secular Ark, 1983) and her training as a biologist equip her well to examine Darwin's years aboard the Beagle, the subject of eight central chapters. Her blending of the geological and biological findings is deft and informative. Darwin's anthropological observations are also drawn together into a coherent and engaging narrative, setting the stage for the incorporation of 'man's place in nature' into his transformist theory.

The book is aimed at a general audience. Darwin specialists may wish for more detail about the crucial scientific inquiries during the Beagle years. And although the general framework and balance of the discussion is excellent, it would have been strengthed by more judicious use of quotations and illustrations from the unpublished zoology and geology manuscripts and the field notebooks and manuscripts. The Beagle years are typically read in historical reverse in most studies, as if the final cause of the voyage were the creation of the transmutation theory. We need to grasp the problems and issues that were then actually at issue for the young Darwin, problems and issues that may have had little direct bearing on transformism but which might explain many other aspects of his later thought. Browne certainly does not engage in such retrospective readings, and her grasp of the historical documents and literature is superb. But she could have introduced the novice a little more to the scientific, as well as the personal, details.

Voyaging is above all a wonderful read. Browne ends with the metaphor of Down House in the 1840s and $1850 \mathrm{~s}$ as a kind of ship, almost a re-creation of the Beagle, self-contained, with specimens and bottles in order, and children and servants replacing Wickham and Covington as aids in Darwin's research. Over it all stands the Victorian father as a disciplined and able captain, continuing in his study the work begun on the large table of the Beagle wardroom, with all domestic functions subordinated to a scientific mission. The outcome would be one of the more remarkable products of human genius. I look forward to the sequel.

Phillip R. Sloan is director of the Program in History and Philosophy of Science, University of Notre Dame, Notre Dame, Indiana 46556, USA.

\section{Paperback history}

The Path to the Double Helix: The Discovery of DNA by Robert Olby, with a foreword by Francis Crick. Dover, \$13.95, £13.95.

The Eighth Day of Creation: Makers of the Revolution in Blology by Horace Freeland Judson. Penguin, $£ 12$.

First published in 1974 and 1979 respectively, these classic books provide in-depth accounts of the events leading up to the discovery in 1953 by Watson and Crick of the molecular structure of DNA.

Judson, a renowned popularizer of science, is the better writer; and, unlike Olby, he goes on to look at the dramatic development of the basic concepts of molecular biology in the 1950 s.

In his new postscript, however, Olby, a noted historian of science, describes what he perceives to be the different approaches of the two versions: “For him [Judson] Kuhn's 'celebrated fashionable discourses on scientific revolutions' are not well informed on the practices of scientists. Judson prefers to treat scientific development in terms of the 'correspondence principle', in which the inherent conservatism of science is stressed. A new theory has to explain all that was explained by the old one. In this way the cumulative nature of scientific knowledge is preserved. The problem with this view is that it fails to accommodate rejected knowledge. Such knowledge has to be treated as anomalous, ambiguous, mistaken. . . Nor need we exclude tentatively held and vague theories simply because they were advanced with less conviction than were other more successful theories."

The Physicists: The History of a Scientific Community in Modern America by Daniel J. Kevles. Harvard University Press, \$17.95, £14.25. On its original publication in 1971 , this book was heralded as an indispensable introduction to the institutional history of US science. Kevles, a historian of science, traces the social, cultural and political forces behind the growth of physics from the post-Civil War years to the present. The new edition contains a 34-page account of the rise and fall of the Superconducting Super Collider. 